\title{
Effects of Prenatal Hypoxia on Nervous System Development and Related Diseases
}

\author{
Bin Wangt, Hongtao Zeng', Jingliu Liu and Miao Sun* \\ Institute for Fetology, The First Affiliated Hospital of Soochow University, Suzhou, China
}

The fetal origins of adult disease (FOAD) hypothesis, which was proposed by David Barker in the United Kingdom in the late 1980s, posited that adult chronic diseases originated from various adverse stimuli in early fetal development. FOAD

OPEN ACCESS

Edited by:

Sila Ultanir,

Francis Crick Institute,

United Kingdom

Reviewed by:

Ashwin S. Shetty,

Harvard University, United States

Tudor Constantin Badea,

Transilvania University of Braşov,

Romania

${ }^{*}$ Correspondence:

Miao Sun

miaosunsuda@163.com

†These authors have contributed equally to this work

Specialty section:

This article was submitted to

Neurodevelopment,

a section of the journal

Frontiers in Neuroscience

Received: 10 August 2021 Accepted: 05 October 2021

Published: 25 October 2021

Citation:

Wang B, Zeng H, Liu J and Sun M (2021) Effects of Prenatal Hypoxia on

Nervous System Development

and Related Diseases.

Front. Neurosci. 15:755554.

doi: 10.3389/fnins.2021.755554 is associated with a wide range of adult chronic diseases, including cardiovascular disease, cancer, type 2 diabetes and neurological disorders such as schizophrenia, depression, anxiety, and autism. Intrauterine hypoxia/prenatal hypoxia is one of the most common complications of obstetrics and could lead to alterations in brain structure and function; therefore, it is strongly associated with neurological disorders such as cognitive impairment and anxiety. However, how fetal hypoxia results in neurological disorders remains unclear. According to the existing literature, we have summarized the causes of prenatal hypoxia, the effects of prenatal hypoxia on brain development and behavioral phenotypes, and the possible molecular mechanisms.

Keywords: prenatal hypoxia, nervous system, development, behavior, mechanism

\section{INTRODUCTION}

The whole process of pregnancy and delivery is critical for the healthy development of the fetus. Therefore, limited oxygen supply (hypoxia) during pregnancy remains one of the greatest threats to fetal development (Piesova and Mach, 2020). The overall incidence of fetal hypoxia varies greatly among European hospitals, ranging from 0.06 to 2.8\% (Giannopoulou et al., 2018). Although fetal cells and organs have some compensatory responses to hypoxia, they are insufficient to protect the developing brain from severe or chronic hypoxia (Riljak et al., 2016; Piesova et al., 2020). Prenatal hypoxia decreases the number of neurons and synaptic density in the hippocampus, which also alters the release of neurotransmitters (Chen et al., 2020; Camm et al., 2021). Prenatal hypoxia can have adverse effects on the development of the central nervous system (CNS) and may lead to future behavioral disorders. In various studies, offspring exposed to prenatal hypoxia showed dysfunctional changes in brain development, movement, memory and emotion (Giannopoulou et al., 2018; Duran-Carabali et al., 2019; Zhuravin et al., 2019; Piesova and Mach, 2020). Therefore, it is crucial to study the effects of prenatal hypoxia using animal models that can replicate human embryonic development, especially fetal brain development. In this review, we focus on the causes of prenatal hypoxia and the effect of prenatal hypoxia on brain development, synaptic plasticity 


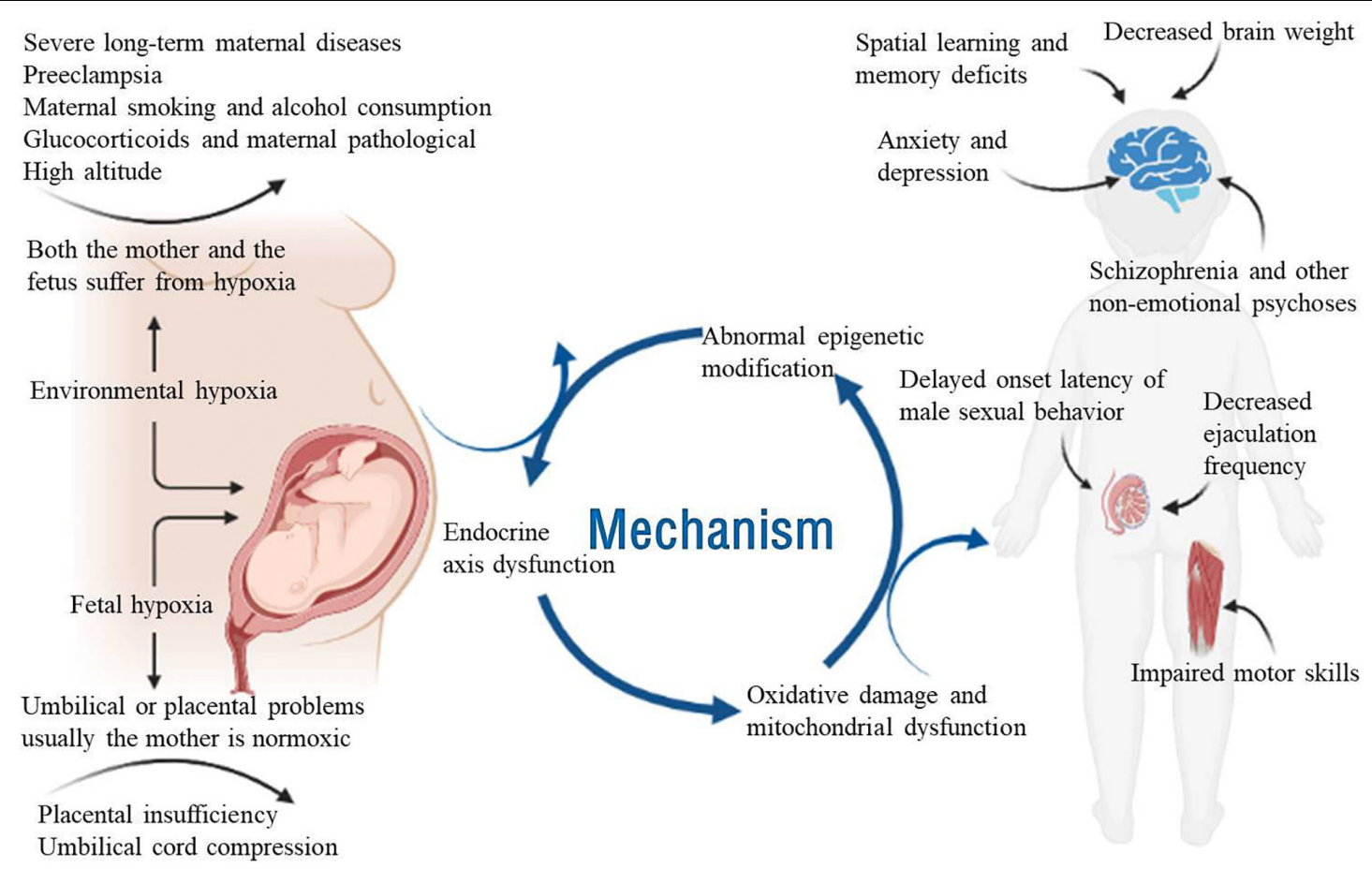

FIGURE 1 | Schematic diagram of the effects of prenatal hypoxia on neurological development and related diseases. Adversity during pregnancy, such as chronic maternal illness, preeclampsia, high-altitude pregnancy, placental dysfunction, and umbilical cord compression, can cause prenatal hypoxia. Adequate oxygen is essential for the growth and development of the fetus. Prenatal hypoxia affects fetal growth and development in terms of epigenetics, endocrine axis dysfunction and mitochondrial oxidative damage. Prenatal hypoxia also causes dysfunction of the offspring after birth, such as learning and memory disorders, male sexual dysfunction, motor dysfunction and emotional disorders.

and behavior and summarize the possible mechanisms involved (Figure 1).

\section{PRENATAL HYPOXIA}

\section{Cause of Prenatal Hypoxia}

Prenatal hypoxia caused by abnormal pregnancy, maternal infection and labor can affect the developmental and behavioral characteristics of animals (Gabrielli et al., 2012). According to the cause of prenatal hypoxia, hypoxia can be divided into two types: environmental hypoxia due to changes in the external or maternal environment, in which both the mother and the fetus suffer from hypoxia, and fetal hypoxia. It may be caused by umbilical or placental problems, and usually the mother is normoxic (Piesova and Mach, 2020).

Factors leading to intrauterine hypoxia include severe longterm maternal diseases (including heart, lung and kidney diseases), pregnancy with anemia, hemoglobinopathy, placental insufficiency, maternal infection, umbilical cord compression, alcohol consumption, maternal smoking, preeclampsia, and administration of glucocorticoids (Sandau and Handa, 2007; Gabrielli et al., 2012; Gonzalez-Rodriguez et al., 2014; Gumusoglu et al., 2020; Piesova and Mach, 2020). Altitudes above 2,500 m are considered high altitude, which is also one of the reasons for prenatal hypoxia. There are approximately 140 million people living in high-altitude environments worldwide, compared with sea level. Pregnancy at high altitude may lead to a significant decrease in maternal arterial $\mathrm{pO}_{2}$ and affect placental growth (Zamudio, 2003; Patterson and Zhang, 2010).

When there is a brief hypoxia attack to the mother during pregnancy, the uterine artery contracts or compresses, which will reduce the amount of oxygen that is delivered to the placenta. The placenta is the main interface between the mother and the fetus, and its development and placental oxygen consumption also affect fetal oxygen supply. In addition, changes in maternal $\mathrm{pO}_{2}$ and/or abnormal placental development or metabolism may reduce $\mathrm{pO}_{2}$ in the fetal arteries and lead to fetal hypoxia (Jensen et al., 1999; Myatt, 2006).

\section{Animal Models Used for Prenatal Hypoxia Studies}

In recent years, to better understand the effects of prenatal hypoxia on brain development and the molecular mechanism in offspring, animal models of prenatal hypoxia have been widely used and reviewed, including rats, mice, rabbits, chickens, and sheep (Table 1).

For humans, a growing number of clinical, epidemiological, and experimental studies in recent years have demonstrated that maternal hypoxia plays a critical role in brain development and postnatal life, which increases vulnerability to later development of neuropsychiatric and neurodegenerative diseases, including 
TABLE 1 | Animal models used for prenatal hypoxia studies.

\begin{tabular}{|c|c|c|c|c|c|c|c|}
\hline Species & Method & Offspring influence & References & Species & Method & Offspring influence & References \\
\hline Human & $\begin{array}{l}\text { Autopsy of the human } \\
\text { neonate to perinatal } \\
\text { hypoxia/ischemia }\end{array}$ & $\begin{array}{l}\text { Neurological and/or } \\
\text { cognitive deficits, } \\
\text { dopaminergic } \\
\text { neurotransmitter } \\
\text { dysfunction }\end{array}$ & $\begin{array}{l}\text { Giannopoulou } \\
\text { et al., } 2018\end{array}$ & \multirow[t]{2}{*}{ Mouse } & \multirow[t]{2}{*}{$\begin{array}{l}\text { Mice were placed in a } \\
\text { Plexiglas chamber filled } \\
\text { with a mixture of } 9 \% \\
\mathrm{O}_{2}, 3 \% \mathrm{CO}_{2} \text {, and } \\
\text { balanced } \mathrm{N}_{2} \text { for } 2 \mathrm{~h}\end{array}$} & \multirow{2}{*}{$\begin{array}{l}\text { High susceptibility of } \\
\text { neonatal seizures and } \\
\text { epilepsy, impaired } \\
\text { migration signaling, } \\
\text { motor disabilities, and } \\
\text { memory damage in } \\
\text { adult offspring }\end{array}$} & \multirow[t]{2}{*}{$\begin{array}{l}\text { Golan et al., 2004, } \\
\text { 2009; } \\
\text { Louzoun-Kaplan } \\
\text { et al., } 2008\end{array}$} \\
\hline Human & Not mentioned & $\begin{array}{l}\text { Cognitive disorders, } \\
\text { Alzheimer's disease }\end{array}$ & $\begin{array}{l}\text { Nalivaeva et al., } \\
2018\end{array}$ & & & & \\
\hline Human & Not mentioned & $\begin{array}{l}\text { Attention- } \\
\text { deficit/hyperactivity } \\
\text { disorder }\end{array}$ & $\begin{array}{l}\text { Getahun et al., } \\
\text { 2013; Owens and } \\
\text { Hinshaw, } 2013\end{array}$ & \multirow[t]{2}{*}{ Sheep } & $\begin{array}{l}\text { The fetus was intubated } \\
\text { through the umbilical } \\
\text { cord vasculature to a }\end{array}$ & \multirow{2}{*}{$\begin{array}{l}\text { Increase of white } \\
\text { matter vessels, the } \\
\text { decrease of neuronal } \\
\text { density and the } \\
\text { damage of myelination }\end{array}$} & \multirow[t]{2}{*}{$\begin{array}{l}\text { Lawrence et al., } \\
2019\end{array}$} \\
\hline Rat & $\begin{array}{l}\text { Exposure to acute } \\
\text { hypoxia on day } 14 \text { of } \\
\text { pregnancy }\end{array}$ & $\begin{array}{l}\text { The number of } \\
\text { synaptopodin-positive } \\
\text { dendritic spines was } \\
\text { reduced, learning and } \\
\text { memory deficits }\end{array}$ & $\begin{array}{l}\text { Vasilev et al., 2016; } \\
\text { Zhuravin et al., } \\
2019\end{array}$ & & $\begin{array}{l}\text { pumpless } \\
\text { extracorporeal } \\
\text { oxygenator for } \\
22 \pm 2 \text { days in } \\
\text { mid-gestation. }\end{array}$ & & \\
\hline Rat & $\begin{array}{l}\text { Uterine artery ligation } \\
\text { on the 16th day of } \\
\text { pregnancy }\end{array}$ & $\begin{array}{l}\text { Pax6 immunoreactivity } \\
\text { showed diverse } \\
\text { patterns in the } \\
\text { neurogenic zone }\end{array}$ & So et al., 2017 & \multirow[t]{2}{*}{ Sheep } & $\begin{array}{l}\text { Fetal lambs } \\
(111 \pm 3 \text { days) were } \\
\text { oxygen delivery was } \\
\text { limited by the umbilical }\end{array}$ & \multirow[t]{2}{*}{$\begin{array}{l}\text { Altered cerebrovascular } \\
\text { resistances and loss of } \\
\text { brain mass }\end{array}$} & \multirow[t]{2}{*}{$\begin{array}{l}\text { McGovern et al., } \\
2020\end{array}$} \\
\hline Rat & $\begin{array}{l}\text { Pregnant female rats } \\
\text { were injected with } 5 \text {, } \\
25 \text {, and } 50 \mathrm{mg} / \mathrm{kg} \\
\text { sodium nitrite }\end{array}$ & $\begin{array}{l}\text { Impaired spatial } \\
\text { memory }\end{array}$ & $\begin{array}{l}\text { Sosedova et al., } \\
2019\end{array}$ & & $\begin{array}{l}\text { circuit oxygenator } \\
\text { maintained in the } \\
\text { artificial womb for a } \\
\text { mean of } 22 \pm 6 \text { days }\end{array}$ & & \\
\hline Rat & $\begin{array}{l}\text { Unilateral ligation of } \\
\text { uterine artery at E17 }\end{array}$ & $\begin{array}{l}\text { White and gray matter } \\
\text { damage, myelin loss, } \\
\text { motor, sensorimotor } \\
\text { and short-term memory } \\
\text { deficits }\end{array}$ & $\begin{array}{l}\text { Delcour et al., } \\
2012 b\end{array}$ & \multirow[t]{2}{*}{ Sheep } & $\begin{array}{l}\text { Pregnant ewes } \\
\text { undergo a sterile } \\
\text { procedure between } 88 \\
\text { and } 92 \text { days of } \\
\text { gestational age to }\end{array}$ & \multirow[t]{2}{*}{$\begin{array}{l}\text { Destroy the dendration } \\
\text { and activity of neurons } \\
\text { in the subplate of } \\
\text { preterm fetal sheep }\end{array}$} & \multirow[t]{2}{*}{$\begin{array}{l}\text { McClendon et al., } \\
2017\end{array}$} \\
\hline Rat & $\begin{array}{l}\text { Clamping of the uterine } \\
\text { vascular system of } \\
\text { pregnant rats at } \\
17 \text { days gestation for }\end{array}$ & Learning deficit & Cai et al., 1999 & & $\begin{array}{l}\text { control blood flow to } \\
\text { the brain through the } \\
\text { common carotid artery } \\
\text { and vertebral artery. }\end{array}$ & & \\
\hline & 30 min & & & \multirow[t]{3}{*}{ Sheep } & Pregnant sheep & \multirow{3}{*}{$\begin{array}{l}\text { Profound brain } \\
\text { inflammation and } \\
\text { mobilization of the } \\
\text { peripheral innate } \\
\text { immune system }\end{array}$} & \multirow[t]{3}{*}{ Jellema et al., 2013} \\
\hline Rat & $\begin{array}{l}\text { (E14 or E18) subjected } \\
\text { to acute normoxia ( } 7 \% \\
\mathrm{O}_{2} \text { within } 3 \mathrm{~h} \text { ) }\end{array}$ & $\begin{array}{l}\text { Physiological } \\
\text { development and } \\
\text { formation of motor } \\
\text { behavior delayed, } \\
\text { learning ability and } \\
\text { memory impaired }\end{array}$ & $\begin{array}{l}\text { Dubrovskaia and } \\
\text { Zhuravin, } 2008\end{array}$ & & $\begin{array}{l}\text { recelved instrumental } \\
\text { treatment at } \\
101 \pm 1 \text { days, and } \\
\text { preterm instrumental } \\
\text { fetal sheep received } \\
25 \text { min of umbilical cord } \\
\text { occlusion at } 0.7\end{array}$ & & \\
\hline \multirow[t]{2}{*}{ Rat } & \multirow{2}{*}{$\begin{array}{l}\text { Pregnant rats treated } \\
\text { with hypoxia }(10.5 \% \\
\mathrm{O}_{2} \text { ) on days } 4-21 \text { of } \\
\text { pregnancy }\end{array}$} & \multirow{2}{*}{$\begin{array}{l}\text { Impaired learning and } \\
\text { memory ability, spatial } \\
\text { acquisition, and } \\
\text { retrieval deficits }\end{array}$} & \multirow[t]{2}{*}{ Wei et al., 2016} & & pregnancy & & \\
\hline & & & & \multirow[t]{4}{*}{ Sheep } & $\begin{array}{l}\text { Pregnant sheep were } \\
\text { surgically instrumented } \\
\text { at gestational day }\end{array}$ & \multirow{4}{*}{$\begin{array}{l}\text { Reduced the vascular } \\
\text { agonist-mediated } \\
\text { contraction in fetal } \\
\text { middle cerebral arteries }\end{array}$} & \multirow[t]{3}{*}{ Su et al., 2020} \\
\hline Rat & $\begin{array}{l}\text { Transient occlusion of } \\
\text { uterine perfusion }\end{array}$ & $\begin{array}{l}\text { Hippocampal injury and } \\
\text { cognitive defects, } \\
\text { induced both } \\
\text { mitochondrial } \\
\text { impairment and } \\
\text { mitochondrial } \\
\text { biogenesis }\end{array}$ & Jia et al., 2020 & & $\begin{array}{l}122 \pm 3 \text { days, the } \\
\text { umbilical cord was } \\
\text { compressed until the } \\
\text { fetal arterial partial } \\
\text { pressure of oxygen } \\
\text { dropped to } 50 \% \text { for } \\
30 \text { min, and the }\end{array}$ & & \\
\hline Rat & $\begin{array}{l}4 \text { h/day throughout } \\
\text { pregnancy (E1-E21) }\end{array}$ & $\begin{array}{l}\text { Sex-dependent } \\
\text { anxiety-like behavior }\end{array}$ & Wang et al., 2013 & & $\begin{array}{l}\text { hypoxia treatment was } \\
\text { repeated every day for }\end{array}$ & & \\
\hline \multirow[t]{2}{*}{ Rat } & On the 18th day of & Increased anxiety-like & Sab et al., 2013 & & 5 days & & \\
\hline & $\begin{array}{l}\text { pregnancy, the } \\
\text { maternal uterine artery } \\
\text { was blocked with } \\
\text { aneurysm clamp for } \\
45 \text { min }\end{array}$ & $\begin{array}{l}\text { behavior and lack of } \\
\text { habits and a lack of } \\
\text { habituation }\end{array}$ & & \multirow[t]{2}{*}{ Chick } & $\begin{array}{l}\text { During the } 21 \text { day } \\
\text { incubation, } 50 \% \text { of the } \\
\text { eggshell was covered } \\
\text { with impermeable } \\
\text { membrane for } 4 \text { or }\end{array}$ & \multirow[t]{2}{*}{ Memory impairment } & \multirow[t]{2}{*}{ Camm et al., 2001} \\
\hline Mouse & $\begin{array}{l}\text { Mice were exposed to } \\
\text { systemic hypoxia at } \\
\mathrm{E} 19.5\left(\mathrm{O}_{2} \text { fraction of }\right. \\
6 \% \text { for } 6 \mathrm{~h})\end{array}$ & Neuronal apoptosis. & Chen et al., 2015 & & $\begin{array}{l}8 \text { days from day } 14 \text { and } \\
\text { day } 10 \text { to limit the gas } \\
\text { exchange of the } \\
\text { eggshell }\end{array}$ & & \\
\hline
\end{tabular}

(Continued)
TABLE 1 | (Continued)

Altered cerebrovascular McGovern et al., resistances and loss of 2020

$111 \pm 3$ days) were en delivery was circuit oxygenato maintained in the artificial womb for and vertebral artery. received instrumenta treatment a

$1 \pm 1$ days, and 25 min of umbilical cord clusion at 0.7 $22 \pm 3$ days, the etal arterial partial pressure of oxygen (loped to $50 \%$ for incubation, $50 \%$ of the 8 days from day 14 and exchange of the at gestational day 
TABLE 1 | (Continued)

\begin{tabular}{|c|c|c|c|}
\hline Species & Method & $\begin{array}{l}\text { Offspring } \\
\text { influence }\end{array}$ & References \\
\hline Chick & $\begin{array}{l}\text { On days } 10-18 \text { or } \\
14-18 \text { of incubation, } \\
\text { half-wrap the eggs in } \\
\text { impermeable } \\
\text { membrane }\end{array}$ & $\begin{array}{l}\text { Cognitive } \\
\text { impairment }\end{array}$ & Camm et al., 2005 \\
\hline Rabbit & $\begin{array}{l}\text { Uterine ischemia lasting } \\
30,37,38 \text {, or } 40 \text { min at } \\
21-22 \text { days gestation }\end{array}$ & $\begin{array}{l}\text { Hypertonia and } \\
\text { abnormalities in } \\
\text { motor control }\end{array}$ & Derrick et al., 2004 \\
\hline Guinea pig & $\begin{array}{l}\text { Unilateral uterine artery } \\
\text { ligation on 30-32 days } \\
\text { of pregnancy }\end{array}$ & $\begin{array}{l}\text { Decreased survival } \\
\text { of neurons in the } \\
\text { cerebral cortex }\end{array}$ & Chung et al., 2015 \\
\hline Guinea pig & $\begin{array}{l}\text { On GD 52, pregnant } \\
\text { females were placed in } \\
\text { a plexiglass chamber } \\
\text { containing } 10.5 \% \mathrm{O}_{2} \\
\text { for } 10 \text { days }\end{array}$ & $\begin{array}{l}\text { Decreased the } \\
\text { density of NeuN- } \\
\text { immunoreactive } \\
\text { neurons in the CA1 } \\
\text { region of the } \\
\text { hippocampus }\end{array}$ & $\begin{array}{l}\text { Blutstein et al., } \\
2013\end{array}$ \\
\hline
\end{tabular}

ADHD, depression, anxiety, Parkinson's disease, and Alzheimer's disease (Nalivaeva et al., 2018). Around the world, $11.1 \%$ of live births worldwide are premature (born before 37 weeks of gestation) each year, and this proportion appears to be increasing (Blencowe et al., 2013). Prenatal hypoxia seriously affects the growth and development of the fetus, leading to low birth weight, premature birth and ischemic hypoxic encephalopathy, and severe cases can directly lead to fetal asphyxia death (Bennet et al., 2012). The incidence of neonatal brain injury in preterm infants is high, and has adverse effects on motor, social, behavioral, cognitive, attention, and sensory outcomes (Getahun et al., 2013; Owens and Hinshaw, 2013; Gopagondanahalli et al., 2016; Giannopoulou et al., 2018; Nalivaeva et al., 2018).

Rats and mice are the most popular and convenient rodent models, and both can be used in prenatal hypoxia studies. In rats, when hypoxia was induced by unilateral uterine artery ligation on the 16th day of pregnancy, Pax6, which plays an important role in neurogenesis, showed diverse patterns in the neurogenic zone (So et al., 2017). In addition, different rat models of prenatal hypoxia showed different degrees of learning and memory deficits (Cai et al., 1999; Dubrovskaia and Zhuravin, 2008; Delcour et al., 2012b; Vasilev et al., 2016; Wei et al., 2016; Sosedova et al., 2019; Zhuravin et al., 2019; Jia et al., 2020). Prenatal hypoxia (4 h/day throughout pregnancy) induces sex-dependent demethylation of the $\mathrm{CpG}$ site of the Crhr1 gene in the male promoter region, resulting in increased Crhr1 mRNA in the PVN region and anxietylike behavior in adult offspring (Wang et al., 2013). On the 18th day of pregnancy, the maternal uterine artery was blocked with an aneurysm clip for $45 \mathrm{~min}$, and the resulting prenatal hypoxia was also characterized by increased anxiety behavior and lack of habituation (Sab et al., 2013). In mice, gestation of wild-type C57BL/6J mice exposed to systemic hypoxia $\left(\mathrm{O}_{2}\right.$ fraction of $6 \%$ for $6 \mathrm{~h}$ ) at E19.5 increased the expression of c-myc, leading to increased Apaf-1 levels through inhibition of
miR-23b-27b cluster expression, which enhanced the sensitivity of neurons to apoptosis (Chen et al., 2015). Pregnant mice were placed in a Plexiglas chamber filled with a gas mixture of $9 \%$ oxygen, $3 \%$ carbon dioxide and balanced nitrogen for $2 \mathrm{~h}$, which induced a decrease in key protein levels of the GABA pathway in the cerebral cortex and may lead to high susceptibility to neonatal seizures and epilepsy, impaired migration signaling in the hippocampus, motor disabilities and memory damage in adult offspring (Golan et al., 2004, 2009; Louzoun-Kaplan et al., 2008).

Sheep, as one of the large experimental animals, is considered the most suitable model for fetal studies because the fetal reaction can be observed directly through recording electrocorticograms (ECOGs) in utero (Lacan et al., 2020). Mid-gestation fetuses were intubated through the umbilical cord vessels in a pumpless extracorporeal oxygenator and supported for $22 \pm 2$ days under hypoxic conditions in a fluid-filled environment, leading to an increase in white matter vessels, a decrease in neuronal density and damage to myelination (Lawrence et al., 2019). Fetal lambs (111 \pm 3 days) with oxygen delivery were limited by the umbilical circuit oxygenator maintained in the artificial womb for a mean of $22 \pm 6$ days, leading to altered cerebrovascular resistances and loss of brain mass (McGovern et al., 2020). Pregnant ewes bred in time underwent aseptic surgery between 88 and 92 days gestational age to control the flow of blood to the brain through the common carotid and vertebral arteries and to disrupt maturation of arborization and activity in preterm fetal ovine subplate neurons (McClendon et al., 2017). Preterm instrumented fetal sheep were exposed to 25 min of umbilical cord blockade at 0.7 gestation, resulting in profound microglial activation and proliferation in the hippocampus, periventricular and subcortical white matter, leading to severe brain atrophy, hypomyelination, region-specific preOL vulnerability, and continuously inhibited brain function, providing evidence of global hypoxia-ischemia leading to profound brain inflammation and mobilization of the peripheral innate immune system (Jellema et al., 2013). Pregnant sheep were surgically instrumented at gestational day $122 \pm 3$ days, the catheters were inserted into the fetal femoral arteries on both sides, and an inflatable occluder was placed around the umbilical cord. Five to seven days after the operation, the umbilical cord was compressed to reduce the umbilical blood flow until the fetal arterial partial pressure of oxygen dropped to $50 \%$ of the baseline lasted for $30 \mathrm{~min}$, and the hypoxia treatment was repeated every day for 5 days. It was found that prenatal hypoxia reduced the vascular agonist-mediated contraction of fetal middle cerebral arteries (Su et al., 2020).

Other animals can also be used in prenatal hypoxia studies. For chicks, prenatal hypoxia can also lead to memory deficits (Camm et al., 2001, 2005). For rabbits, uterine ischemia lasting $30,37,38$, or $40 \mathrm{~min}$ at 21-22 days gestation can lead to hypertonia and abnormalities in motor control (Derrick et al., 2004). For guinea pigs, prenatal hypoxia resulted in decreased survival of neurons in the cerebral cortex and decreased the density of $\mathrm{NeuN}$-immunoreactive neurons in the CA1 region of the hippocampus (Blutstein et al., 2013; Chung et al., 2015). 


\section{CONSEQUENCES OF PRNATAL HYPOXIA IN NEURAL SYSTEMS}

\section{Abnormal Brain Development}

The brain has the highest aerobic metabolism of all body organs, resulting in the greatest demand for oxygen and nutrients (Koundal et al., 2014). The adult central nervous system (CNS) is sensitive to hypoxia due to the lack of sufficient antioxidant enzymes and substrate reserves required for anaerobic metabolism (Esih et al., 2017; Piesova and Mach, 2020). Although it is generally believed that cerebral ischemia and hypoxia have similar properties, the characteristic of ischemia is usually accompanied by reducing or blocking the blood flow in some brain regions and leading to irreversible neuronal damage, whereas hypoxia leads to increased cerebral blood flow, which may lead to permanent or reversible changes in neuronal function, depending on its severity (Miyamoto and Auer, 2000). The effects of hypoxia and ischemia on developing brain cells are diverse: from the loss of neurons and oligodendrocytes to gliosis, changes in cell differentiation, decreases in synapse formation, and changes in neurotransmitter levels, even leading to irreversible cell injury and cell death (Robinson et al., 2005; Zhang et al., 2013). Studies in rodents have shown that chronic hypoxia can lead to anatomical changes similar to those seen in preterm infants, such as volume loss, reduced myelination and ventricular enlargement (Mayoral et al., 2009). In fact, in embryonic guinea pigs with maternal hypoxia, neural density, as measured by NeuN immunoreactivity in the CA1 field, was significantly decreased and GFAP and $\mathrm{NeuN}$ were significantly reduced in the CA1 region in adulthood (Blutstein et al., 2013), which also indicated that prenatal hypoxia could exert effects on neuronal development in the long term.

\section{Impaired Synaptic Plasticity}

In terms of cellular mechanisms, hippocampal synaptic plasticity, including long-term potentiation (LTP) and longterm depression (LTD), is thought to underlie certain types of learning and memory (Collingridge et al., 2004). Impairment of brain function due to prenatal hypoxia is associated with impaired neurotransmitter circuits and synaptic plasticity (Herlenius and Lagercrantz, 2004). In rat offspring subjected to maternal hypoxia at E14 (Embryonic day 14), a decrease in the total number of pyramidal cortical neurons and the density of fragile synaptopodin-positive dendritic spines were observed, which subsequently differentiated into V-VI layer and formed cortical microcolumn and formation of cortical columns affects the formation of cortical cell structure, neuronal plasticity and postnatal behavior, which demonstrates cortical dysfunction (Vasilev et al., 2016). In normal aging rats, the number of synaptopodin-positive dendritic spines decreased, which may be one of the reasons for the decline in cognitive ability in Alzheimer's disease (Arnold et al., 2013). Moreover, prenatal hypoxia significantly interfered with the basic synaptic transmission of CA3-CA1 synapses, with a twofold decrease in hippocampal LTP, decline in the protein level of GluN2B and reduced positive dendritic spines in the CA1 region of the hippocampus (Zhuravin et al., 2019). The decrease in the number of dendritic spines in the hippocampal CA1 region may be related to changes in the entorhinal cortex, which is thought to be the earliest event in the development of Alzheimer's disease in humans (Killiany et al., 2002; Nalivaeva et al., 2018).

\section{Dysfunction of Key Pathways in Brain Hypoxia-Inducible Factor 1 Pathway}

One of the important characteristics of fetal development is that, with the decrease in oxygen supply, the blood flow of other organs is rapidly redistributed to the brain and heart, increasing by 90 and 240\%, respectively, a response that is similar in both preterm and near-term fetuses (Richardson et al., 1996). In general, the initial response to hypoxia at the cellular level leads to changes in the expression of hypoxia inducible factor (HIF), which regulates many genes, including almost all genes involved in the glycolysis pathway (Semenza, 1998). It helps organisms to improve their survival ability under hypoxia by promoting erythropoiesis, vasodilation and angiogenesis. Prenatal hypoxia has been shown to change the expression of HIF-1 $\alpha$ in the brains of embryonic rats, depending on the developmental stage of the embryo (Royer et al., 2000). Short and prolonged hypoxia induces a biphasic response to CRHR1 mRNA characterized by an initial decrease followed by a sustained increase and activation of the HPA axis, inducing hypoxic disease and behavioral changes. In this process, HIF$1 \alpha$ plays an active control role at the CRHR 1 promoter -p1218 to -p1140 (Shi et al., 2017). At E14, it was found that hypoxia during pregnancy increased HIF-1 $\alpha$; however, hypoxia on E19 did not lead to any response in the HIF-1 $\alpha$ genes, which indicates the difference in adaptability to hypoxia in these developmental stages (Royer et al., 2000).

\section{Inflammation/Immunological Pathway}

Inflammatory mediators are multifunctional cytokines that may be synthesized and secreted by several CNS cell types, including microglia, astrocytes and neurons, of which interleukin (IL)-1 $\beta$, tumor necrosis factor- $\alpha$ (TNF- $\alpha$ ) and IL- 6 are among the most typical early responses, playing both a normal CNS development and a brain response to various forms of injury important role (Saliba and Henrot, 2001). A population-based survey found that the level of IL-6 in cerebrospinal fluid after perinatal asphyxia correlated with the severity of neonatal hypoxicischemic encephalopathy (HIE), brain injury and neurological outcome, suggesting a role for IL-6 in neonatal hypoxic-ischemic brain injury (Martin-Ancel et al., 1997). Another investigation showed that preterm infants with MRI-defined brain white matter injury had higher levels of IL-6, IL-10, and TNF- $\alpha$ in the CSF than infants without such injury. Elevated cytokine levels in the CSF of infants with cerebral white matter injury suggest altered inflammatory homeostasis (Ellison et al., 2005). In addition, pregnant Sprague-Dawley (SD) rats were dissected, inhaled oxygen concentrations were reduced to $10 \%$ for 3,5 , or $7 \mathrm{~min}$ to induce hypoxia, and mild hypoxic ischemia (HI) resulted in elevated IL- $1 \beta$ and IL- 6 but not TNF- $\alpha$ mRNA and 
protein in brain and blood samples of the offspring at postnatal day 30 (Driscoll et al., 2018). NF- $\kappa \mathrm{B}$ is rapidly activated in neurons and glial cells after asphyxial injury, and NF- $\kappa$ B p65 was shown to be upregulated in the rat brain $10 \mathrm{~min}$ after perinatal asphyxia, leading to the induction of genes associated with the innate immune response (Lubec et al., 2002; Morales et al., 2011).

\section{Neurotrophic Pathway}

Neurotrophic signaling is critical to prenatal and postnatal brain development because it affects the neuronal development process and its response to perinatal stress (Giannopoulou et al., 2018). Members of the neurotrophin family, including brainderived neurotrophic factor (BDNF), nerve growth factor (NGF), neurotrophin-3 (NT-3), and neurotrophin-4 (NT-4), play a basic role in brain function and neuroprotection (Hennigan et al., 2007). Downregulation of BDNF was detected in umbilical cord samples from perinatal asphyxia (PA) patients who developed schizophrenia in adulthood (Cannon et al., 2008). Unilateral uterine artery ligation of Dunkin-Hartley guinea pigs at 3032 days of gestation revealed a decrease in the number of neuronal cells in the cerebral cortex associated with a decrease in BDNF protein (Chung et al., 2015). Intrauterine growth restricted (IUGR) cases are characterized by intrauterine hypoxia, and NGF decreased significantly in the IUGR group compared with the fetus at the appropriate gestational age (MalamitsiPuchner et al., 2007). Another study suggested that NT3 and NT4 decreased after hypoxia ischemia, while NGF and BDNF increased (Nikolaou et al., 2006).

\section{Amyloid- $\beta$ Peptide Related Pathway}

The current majority view is that cases of Alzheimer's disease (AD) are caused by an interaction between genetic and environmental factors. Hypoxia is considered to be an important environmental factor influencing the development of $\mathrm{AD}$. Exposure of pregnant APP(Swe)/PS1(A246E) transgenic mice to hypoxia during gestation days 7-20 revealed higher levels of amyloid precursor protein (APP), lower levels of the $A \beta$ degrading enzyme neprilysin, increased $A \beta$ accumulation in the brains of prenatal hypoxic mice, and neuropathological changes mainly showing increased tau phosphorylation and enhanced activation of astrocytes and microglia (Zhang et al., 2013). Jackson Black C57 mice were exposed to $3 \% \mathrm{CO}_{2} / 9 \%$ $\mathrm{O}_{2}$ for $2 \mathrm{~h}$ on the 17th day of pregnancy, and the content of APP in the hippocampus decreased significantly (Golan et al., 2009). In addition, prenatal hypoxia $\left(7 \% \mathrm{O}_{2}, 3 \mathrm{~h}\right.$, E14) in aged male Wistar rats (over 12 months) or adult male rats (3-4 months) resulted in reduced expression of cortical metallopeptidases endothelin-converting enzyme (ECE1) and neprilysin (NEP), two enzymes that regulate certain neuropeptides and are major $\beta$-amyloid degrading enzymes (Dubrovskaia et al., 2009).

\section{Prenatal Hypoxia Affects Brain Function in Long Term}

Hypoxia is one of the main causes of brain damage with long-lasting behavioral implications (Golan and Huleihel, 2006).
Different brain development and behavioral defects may be directly related to different ages and injury sites after hypoxia injury during pregnancy, which is worthy of attention. The effects of prenatal hypoxia on offspring of different ages are summarized in Table 2.

For humans and newborns with HIE, MRI studies show structural damage in the cortex and white matter at the age of 2 years (Martinez-Biarge et al., 2010). In another study, perinatal hypoxic-ischemic injury resulted in severe cognitive impairment, moderate to severe cerebral palsy and death at the age of 2 years (Twomey et al., 2010). Studies have shown that hypoxia during pregnancy is closely related to children's attention deficit hyperactivity disorder (ADHD) (Zhu et al., 2016; Banhegyi et al., 2020). After a 19-year follow-up of 693 men and women (average age 23) born between 1959 and 1966 who were evaluated in early childhood, researchers found that schizophrenia and other non-emotional psychoses were strongly associated with prior hypoxic-ischemic events (Zornberg et al., 2000).

For animals, a midline laparotomy was performed with pregnant Sprague-Dawley rats by endotracheal intubation around pregnancy day 18. Prenatal hypoxia leads to the loss of oligodendrocyte lineage cells and cortical neurons, increased cell death, reduced cell proliferation, elevated pro-inflammatory cytokine levels at P2, and impaired motor skills at a young age (Robinson et al., 2005). The fetus containing the uterine horn was immersed in a $37^{\circ} \mathrm{C}$ water bath for $20 \mathrm{~min}$ at $\mathrm{P} 0$, the number of TUNEL-positive cells in asphyctic rats was 40 and $45 \%$ on P8 and P15, respectively, and the total number of striatal neurons in asphyctic young rats decreased by $16 \%$ on the 21 st day. These data suggest that asphyxia leads to excessive apoptotic cell death in the first week of life, resulting in the loss of a small number of neurons in the neostriatum (Van de Berg et al., 2002). With acute normobaric hypoxia on E14 or E18 (3 h at $7 \% \mathrm{O}_{2}$ ), prenatal hypoxia can delay the establishment of physiological development and motor behavior in the first month after birth (Dubrovskaya and Zhuravin, 2010). Rats treated with hypoxia (10.5\% oxygen) from day 4 to day 21 of pregnancy significantly decreased brain weight and spatial learning and memory deficits in offspring 6 weeks after birth (Wei et al., 2016). Pregnant Sprague-Dawley females were exposed to continuous hypoxia ( $10.5 \% \mathrm{O}_{2}$ from 15 to day 21 of pregnancy), and prenatal hypoxia significantly delayed the onset latency of male sexual behavior and decreased ejaculation frequency in adult offspring (130 days) but did not show a significant increase in female sexual potential (Hermans et al., 1993). In addition, prenatal hypoxia can also lead to adult offspring (4-6 months) motor disabilities and memory damage (Golan et al., 2004).

\section{Abnormal Neurological Behaviors Movement}

Motor skills and coordination develop in the first month of life, such as the ability of the newborn to grasp a rotating bar or grid (Golan and Huleihel, 2006). Brain damage caused by hypoxia has a long-term effect on the behavior of offspring. Children who survived hypoxia-ischemia at delivery suffer from ADHD, 
TABLE 2 | Prenatal hypoxia affects brain function in long term.

\begin{tabular}{|c|c|c|c|c|}
\hline Age test & Prenatal hypoxia conditions & Brain development & Behavior & References \\
\hline 2 years & Not mentioned & $\begin{array}{l}\text { Structural damage in the cortex } \\
\text { and the white matter }\end{array}$ & Not mentioned & Martinez-Biarge et al., 2010 \\
\hline 2 years & Not mentioned & $\begin{array}{l}\text { Severe cognitive impairment, } \\
\text { moderate to severe cerebral } \\
\text { palsy and death }\end{array}$ & Not mentioned & Twomey et al., 2010 \\
\hline Between 2 and 18 years & Not mentioned & Not mentioned & ADHD & $\begin{array}{l}\text { Zhu et al., 2016; Banhegyi } \\
\text { et al., } 2020\end{array}$ \\
\hline $\begin{array}{l}\text { 19-year follow-up of average } \\
\text { age } 23 \text { years }\end{array}$ & Not mentioned & Not mentioned & $\begin{array}{l}\text { Schizophrenia and other } \\
\text { non-emotional psychoses }\end{array}$ & Zornberg et al., 2000 \\
\hline P2 & $\begin{array}{l}\text { Rats around E18 via } \\
\text { endotracheal intubation, an } \\
\text { aneurysm clip placed on the } \\
\text { arteries, removed after } 45 \text { min }\end{array}$ & $\begin{array}{l}\text { Lacking oligodendrocyte and } \\
\text { cortical neurons, cell } \\
\text { proliferation decreased, cell } \\
\text { death increased, and the level } \\
\text { of pro-inflammatory cytokine } \\
\text { levels increased at P2 }\end{array}$ & $\begin{array}{l}\text { Impaired motor skills as young } \\
\text { adults }\end{array}$ & Robinson et al., 2005 \\
\hline P2, P8, P15 & $\begin{array}{l}\text { The rat uterine horn containing } \\
\text { the fetus was immersed in a } \\
37^{\circ} \mathrm{C} \text { water bath for } 20 \text { min at } \\
\text { PO }\end{array}$ & $\begin{array}{l}\text { Excessive apoptotic cell death } \\
\text { in the first week of life, resulting } \\
\text { in the loss of a small number of } \\
\text { neurons in the neostriatum }\end{array}$ & Not mentioned & Van de Berg et al., 2002 \\
\hline First month of postnatal & $\begin{array}{l}\text { Acute normobaric hypoxia on } \\
\mathrm{E} 14 \text { or } \mathrm{E} 18\left(3 \mathrm{~h} \text { at } 7 \% \mathrm{O}_{2}\right) \text { in } \\
\text { rats }\end{array}$ & $\begin{array}{l}\text { Hypoxia on days } 14 \text { showed } \\
\text { lower body weights, later } \\
\text { separation of the outer ear from } \\
\text { the skin of the head, and later } \\
\text { opening of the eyes, ear from } \\
\text { the skin of the head and later } \\
\text { eye opening, while hypoxia on } \\
\text { day } 18 \text { showed no statistically } \\
\text { significant delay. }\end{array}$ & $\begin{array}{l}\text { Decreased learning ability and } \\
\text { impaired long-term and } \\
\text { short-term memory }\end{array}$ & $\begin{array}{l}\text { Dubrovskaya and Zhuravin, } \\
2010\end{array}$ \\
\hline 6 weeks after birth & $\begin{array}{l}\text { From day } 4 \text { to day } 21 \text { of } \\
\text { gestation, rats were treated } \\
\text { with hypoxia }\left(10.5 \% \mathrm{O}_{2}\right)\end{array}$ & Decreased brain weight & $\begin{array}{l}\text { Spatial learning and memory } \\
\text { deficits }\end{array}$ & Wei et al., 2016 \\
\hline 130 days & $\begin{array}{l}\text { Day } 15-21 \text { of pregnancy, rats } \\
\text { were treated with } 10.5 \% \mathrm{O}_{2}\end{array}$ & Not mentioned & $\begin{array}{l}\text { Delayed onset latency of male } \\
\text { sexual behavior and decreased } \\
\text { ejaculation frequency }\end{array}$ & Hermans et al., 1993 \\
\hline 4-6 months & $\begin{array}{l}\text { Mice were placed in a } \\
\text { plexiglass chamber (filled with a } \\
\text { mixture of } 3 \% \mathrm{CO}_{2} \text { and } 9 \% \mathrm{O}_{2} \text {, } \\
\text { balanced } \mathrm{N}_{2} \text { gas) for } 2 \mathrm{~h}\end{array}$ & $\begin{array}{l}\text { Modified offspring brain } \\
\text { morphology }\end{array}$ & $\begin{array}{l}\text { Motor disabilities and memory } \\
\text { damage }\end{array}$ & Golan et al., 2004 \\
\hline
\end{tabular}

executive functioning disorder and object recognition disorder (Delcour et al., 2012a; Smith et al., 2016; Piesova and Mach, 2020). In animal models, the effects of hypoxia on behavior are similar to those of ADHD. Animals often exhibit motor and learning disabilities, hyperactivity disorder, and decreased memory, socialization, and attention (Piesova and Mach, 2020). Studies have shown that after prenatal hypoxic-ischemic injury, rats exhibit defects in motor skills, including ataxia and delayed motor planning, similar to those of affected infants (Robinson et al., 2005). Although congenital motor response defects in neonatal rats after prenatal hypoxia became less obvious in the first month of life with the development of young rats, more skilled movements, such as reaching and pushing, and learning new motor reflexes, remained compromised in adulthood (Zhuravin et al., 2002).

\section{Memory}

Different from those conditions where pups actually compensated and restored during the first month of development, cognitive impairment caused by prenatal hypoxia at E14 or E18 can still be detected at all testing stages after birth (Nalivaeva et al., 2018). The hippocampus is a part of the limbic system that originates in the medial telencephalon and plays an important role in the encoding of information; it is related to long-term and short-term memory and spatial navigation (Khalaf-Nazzal and Francis, 2013). Prenatal hypoxia causes impairment of different types of memory (short-term memory and long-term memory, working memory) in rat offspring, which is associated with the structural changes observed in the hippocampus (Zhuravin et al., 2011; Nalivaeva et al., 2012; Cunha-Rodrigues et al., 2018). Exposure of pregnant rats to $10.5 \%$ oxygen from day 15 to day 21 of gestation resulted in increased matrix metalloproteinase activity and significant cell death in the hippocampal region of neonatal rats, which was associated with worse neurobehavioral outcomes (Tong et al., 2010). On the other hand, learning deficits in the offspring of adult pregnant rats exposed to hypobaric hypoxia during gestational days 10-20 correlated with a significant reduction in 
the frequency of polyplasmic neurons in the subdentate region (Foley et al., 2005).

\section{Emotion}

Prenatal hypoxia not only changes the behavior of movement and memory but also affects emotion. Pregnant rats during gestational days 19-20 were exposed to low oxygen content $\left(10.5 \% \mathrm{O}_{2}\right)$ for $4 \mathrm{~h}$ per day, and prenatal hypoxic rats had a higher response to the stress stimulus, leading to anxiety- and depression-like behaviors in the offspring (Sedlackova et al., 2014). Animals subjected to asphyxia showed a significant decrease in social aggression, an increase in social contact behavior, and an increase in anxiety levels (Weitzdoerfer et al., 2004). Prenatal hypoxia also resulted in decreased social interaction, impaired male sexual behavior, and decreased acquisition of passive and active avoidance responses (Dubrovskaya and Zhuravin, 2010). In addition, prenatal hypoxia is closely related to schizophrenia (Howell and Pillai, 2016). Interestingly, some early studies have shown that hypoxia during pregnancy does not affect anxiety-like behavior in rats with prenatal hypoxia (Buwalda et al., 1995), while rats exposed to prolonged hypoxia (15 and 20 min of asphyxia) showed a decrease in anxiety-related behavior in the elevated plus maze (Hoeger et al., 2000). These opposite results may be caused by the use of different models and different temporal checkpoints in these studies.

\section{POSSIBLE MECHANISMS UNDERLYING THE NEUROLOGICAL DISORDERS CAUSED BY PRENATAL HYPOXIA}

Although the phenomenon of nervous system development disorders and psychiatric disorders due to prenatal hypoxia has been continuously confirmed, there is no complete and systematic theoretical system of its occurrence. At present, there are many hypotheses about the mechanism: abnormal epigenetic modification, endocrine axis dysfunction, oxidative damage and mitochondrial dysfunction.

\section{Abnormal Epigenetic Modification}

Epigenetic modification is a form of gene regulation of a specific genome that does not change the sequence of DNA nucleotides, but can be stably inherited through a variety of mitotic modes (Bernstein et al., 2007). Epigenetic modifications include DNA methylation, histone modification and non-coding RNA regulation. Epigenetic modification allows phenotypic plasticity, allowing individuals to regulate gene expression through environmental changes, which is a heritable change (Boland et al., 2014). This pattern of gene regulation has attracted increasing attention in development programs. The early adverse intrauterine environment may produce abnormal epigenetic markers, which may lead to metabolic syndrome and other chronic adult diseases after birth (O'Sullivan et al., 2012). Oxygen levels through HIF $1 \alpha$-Notch signaling interactions and DNA demethylation of astrocytic genes epigenetically regulate the fate of neural precursor cells (Mutoh et al., 2012). In the normally developing brain, hypoxic culture conditions $(<5 \%)$ can promote the differentiation of neural precursor cells into astrocytes at midgestation by activating the Notch signaling pathway and upregulating the transcription factor nuclear factor IA (NFIA), which leads to the demethylation of astrocyte-specific genes such as $\mathrm{S} 100 \beta$ and GFAP; however, under normoxic conditions, these processes are inhibited (Mutoh et al., 2012). It is reasonable to suggest that a lower oxygen level will promote the differentiation of astrocytes in the developing brain even more strongly, resulting in a decrease in the ratio of neurons to astrocytes. Maternal hypoxia $\left(10.5 \% \mathrm{O}_{2}, \mathrm{E} 15-21\right)$ leads to a decrease in glucocorticoid receptor expression in the developing rat brain, and decreased GR expression is attributed to increased DNA methylation, reduced binding of transcription factors Sp1 and Egr- 1 to GR gene exon $1_{11}$ and $1_{7}$ promoters, and decreased GR exon $1_{11}$ and $1_{7}$ mRNA variants (Gonzalez-Rodriguez et al., 2014). Gestational intermittent hypoxia (4 h per day, E1-E21, $10.8 \% \mathrm{O}_{2}$ ) induced demethylation of the CPG site of Crhr1 DNA in the promoter in male offspring of Sprague-Dawley rats, which triggered an increase in Crhrl mRNA expression and anxiety-like behavior in adult offspring (Wang et al., 2013). Three-month-old APP(swe)/PS1(dE9) mice exposed to hypoxia for $6 \mathrm{~h} /$ day for 30 days exhibited aggravated AD progression, accompanied by decreased genomic DNA demethylation and DNA methyltransferase 3B (DNMT3b) expression. DNMT inhibition increased amyloid precursor protein and $\beta$ - and $\gamma$-secretase protein expression. In contrast, overexpression of DNMT3b inhibited their levels in vitro (Liu et al., 2016).

Studies have confirmed the role of a unique class of small non-coding microRNAs (miRNAs) in the post-transcriptional regulation of target genes in response to hypoxia (Nguyen et al., 2013). The mechanism of miRNA production and maturation depends on the oxygen supply to the cells, and the regulation of HIF expression depends on the type of miRNA (Taguchi et al., 2008; Liu et al., 2015). Since REST inhibits the expression of neuron-specific proteins and miRNA genes, under hypoxic conditions, the REST content decreases; therefore, reducing the oxygen supply plays a regulatory role in maintaining the miRNA profile of neurons (Liang et al., 2014). In the process of hypoxia-induced embryonic brain cortical apoptosis and neuronal apoptosis, the transcription factor c-myc plays an inhibitory role in regulating the expression of the miR-23b-27b cluster during hypoxia (Chen et al., 2015). In addition, oxygen tension is associated with histone $\mathrm{H} 3$ methylation and coactivator recruitment, chromatin transcriptionally active (euchromatin) or inactive (heterochromatin) depends on histone modifications, and prenatal hypoxia can directly or indirectly inhibit the expression of G6Pase through the increase of histone H3 [K9] methylation (Osumek et al., 2014).

\section{Endocrine Axis Dysfunction}

Intrauterine programming refers to the critical stage of development under unsatisfactory intrauterine conditions (such as hypoxia), which will have irreversible consequences (Sedaghat et al., 2015). The developmental programming hypothesis of the intrauterine endocrine axis is one of the most accepted hypotheses. The endocrine axis mainly includes 
the hypothalamic-pituitary-adrenal (HPA) axis, growth hormone (GH)-insulin-like growth factors (IGFs) and the renin-angiotensin system (RAS) (Fowden and Forhead, 2004; Fowden et al., 2005). The HPA axis is one of the most important neuroendocrine axes and plays an important role in the stress defense response before and after birth. Fetal overexposure to maternal glucocorticoids may be a major initial factor in altering fetal HPA axis programming, and these changes will increase the susceptibility of adult neuropsychiatric disorders, such as schizophrenia and depression, as well as metabolic diseases (Zhang et al., 2014).

It has been shown that glucocorticoids play an important role in neurological function and that high concentrations of glucocorticoids can exacerbate excitotoxic effects and promote neuronal death (Stein-Behrens et al., 1992; Lee et al., 2002; Dumas et al., 2010). Severe prenatal hypobaric hypoxia leads to a persistent increase in the baseline blood levels of corticosterone in adult and aged rats, and the total amount and nuclear localization of GR in the hippocampus of newborn rat pups decrease significantly and persist throughout life (Vetrovoy et al., 2020). Clinical studies have shown that the volume of cortical gray matter in preterm infants treated with synthetic glucocorticoids is reduced and that their long-term neuromotor and cognitive functions are impaired (Murphy et al., 2001; Yeh et al., 2004).

\section{Oxidative Damage and Mitochondrial Dysfunction}

Oxygen is the terminal receptor of electrons in the mitochondrial electron transport chain and is associated with oxidative phosphorylation and energy production through ATP synthesis. If the oxygen supply is reduced or completely blocked, electron transport is slowed down, which will not fully meet the metabolic needs of the cell (Piesova and Mach, 2020). Hypoxia also increases the level of reactive oxygen species (ROS) because it disrupts complexes I and III of the mitochondrial electron transport system, and in a hypoxic environment, the electron flow is slow, so the possibility of superoxide anion formation increases (Poyton et al., 2009). ROS destroy membrane components, induce neuronal apoptosis and damage the cerebrovascular system (Koundal et al., 2014). Prenatal hypoxia also leads to increased placental oxidative stress and decreased mitochondrial respiration and mitochondrial fusion, which may lead to disorders of placental function and fetal development (Ganguly et al., 2021). Increased oxidative stress also leads to damage to proteins, lipids and DNA, which disrupts normal cellular function (Silvestro et al., 2020). Rapid re-oxygenation after hypoxia can disrupt the fetal blood-brain barrier by producing ROS, thereby amplifying the effects of molecules in fetal blood on the brain (Piesova and Mach, 2020).

\section{FUTURE PROSPECTS}

Although the molecular mechanisms of brain development and functional damage caused by prenatal hypoxia have been deeply studied, all the changes in molecules and behavior caused by prenatal hypoxia are not yet fully understood.
Further studies of prenatal hypoxia models will enable us to better understand the mechanism of neuron dysfunction in fetal development and design new prevention strategies to restore brain integrity and normal behavior. Clinically, the use of ultrasound, Doppler velocimetry and antenatal screening for high-risk pregnancies can help identify at-risk fetuses. Interventions such as intrauterine resuscitation or surgical delivery may reduce the risk of severe hypoxia due to intrauterine injury and improve the long-term neurological prognosis.

A number of pharmacological approaches can also be used in pregnant women during pregnancy, and magnesium sulfate $\left(\mathrm{MgSO}_{4}\right)$ is administered to pregnant women with premature birth to prevent the development of cerebral palsy in the infant (Shepherd et al., 2017). Animal studies further showed that $\mathrm{MgSO}_{4}$ was administered to pregnant mice on day 17 of gestation, $4 \mathrm{~h}$ before chamber hypoxia $\left(9 \% \mathrm{O}_{2}, 2 \mathrm{~h}\right)$, reduced motor deficits in the offspring and protected their developing Purkinje cells in the postnatal period (Golan et al., 2004). In a prenatal hypoxic guinea pig model, treatment of hypoxic pregnant female with $\mathrm{MgSO}_{4}$ attenuated the hypoxiainduced increase in $\mathrm{Ca}(2+)$ inward flow in neuronal nuclei of the guinea pig fetus and protected the nuclear membrane function of neuronal cells (Maulik et al., 2005). Maternal $\mathrm{MgSO}_{4}$ treatment also reversed the hypoxia-induced GABA deficit pathway in neonates and reversed the hypoxia-induced loss of inhibitory neuronal subpopulations in neonates (LouzounKaplan et al., 2008). Pretreatment with $\mathrm{MgSO}_{4}$ reduces hypoxiainduced motor deficits in a mouse model of maternal hypoxia and prevents the short-term memory impairment but not long-term memory impairment (Golan et al., 2004). In a rat model of prenatal hypoxia, nimodipine was shown to prevent hypoxia-induced brain growth inhibition in offspring (Nyakas et al., 1994). In addition, valproic acid restored neprilysin (NEP) activity and memory deficits in adult offspring rats caused by prenatal hypoxia, which involves regulating the NEP gene by binding the APP intracellular domain (AICD) to the NEP promoter (Nalivaeva et al., 2012). For memory impairment in hypoxic offspring during pregnancy, it has been shown that maternal vitamin $\mathrm{C}$ supplementation during hypoxic gestation can prevent excessive oxidative stress in the placenta, thereby ameliorating the adverse effects of prenatal hypoxia on hippocampal tissue atrophy and memory loss in adult offspring (Camm et al., 2021). Crocin significantly improves hypoxia in the brain tissue of neonatal rats during pregnancy by improving memory impairment and molecular alterations related to hypoxia (Ghotbeddin et al., 2021).

Some gene therapy methods are also used for hypoxia during pregnancy. Prenatal hypoxia $\left(7 \% \mathrm{O}_{2}, 3 \mathrm{~h}\right)$ in rats on the 14th day of embryonic development increases caspase3 content and activity while decreasing the levels of NEP and AICD, which regulates NEP expression. Increased levels of AICD and NEP were found in hypoxic offspring after a single injection of a caspase inhibitor (i.v., Ac-DEVD-CHO0) (Kozlova et al., 2015). Defective trophoblastic invasion observed in preeclampsia (PE) or fetal growth restriction (FGR) is thought to result in relative placental hypoxia. Tadalafil, a selective phosphodiesterase 5 inhibitor, reduced the expression of HIF- $2 \alpha$ 
in the placenta and in the brain of FGR fetuses, and in utero treatment showed improved synaptogenesis and myelination in FGR offspring at P15 and P30 (Tachibana et al., 2019). Selective head cooling $\left(34.5^{\circ} \mathrm{C}\right)$ and whole-body cooling $\left(33.5^{\circ} \mathrm{C}\right)$ are two hypothermic treatments commonly used as protective therapy for moderate to severe HIE, within the first $6 \mathrm{~h}$ after birth and maintained for 3 days to effectively reduce brain damage (Silveira and Procianoy, 2015). Maternal voluntary exercise during pregnancy can increase the number of hippocampal neurons and angiogenesis and protect against mild chronic postnatal hypoxia in rat offspring (Akhavan et al., 2012). In addition, stem cells, erythropoietin, allopurinol, flunarizine, nitric oxide, and other traditional Chinese medicines and related extracts are also involved in the treatment of HIE (Zhao et al., 2016).

\section{REFERENCES}

Akhavan, M. M., Foroutan, T., Safari, M., Sadighi-Moghaddam, B., EmamiAbarghoie, M., and Rashidy-Pour, A. (2012). Prenatal exposure to maternal voluntary exercise during pregnancy provides protection against mild chronic postnatal hypoxia in rat offspring. Pakist. J. Pharm. Sci. 25, 233-238.

Arnold, S. E., Louneva, N., Cao, K., Wang, L. S., Han, L. Y., Wolk, D. A., et al. (2013). Cellular, synaptic, and biochemical features of resilient cognition in Alzheimer's disease. Neurobiol. Aging 34, 157-168. doi: 10.1016/ j.neurobiolaging.2012.03.004

Banhegyi, M., Hargitai, E., Mikics, E., and Halasz, J. (2020). Description of perinatal adversities in children with attention-deficit/hyperactivity disorder. Psychiatria Hungarica 35, 30-36.

Bennet, L., Davidson, J. O., Koome, M., and Gunn, A. J. (2012). Glucocorticoids and preterm hypoxic-ischemic brain injury: the good and the bad. J. Pregnancy 2012:751694. doi: 10.1155/2012/751694

Bernstein, B. E., Meissner, A., and Lander, E. S. (2007). The mammalian epigenome. Cell 128, 669-681. doi: 10.1016/j.cell.2007. 01.033

Blencowe, H., Cousens, S., Chou, D., Oestergaard, M., Say, L., Moller, A. B., et al. (2013). Born too soon: the global epidemiology of 15 million preterm births. Reproductive Health 10(Suppl. 1):S2. doi: 10.1186/1742-4755-10-S1-S2

Blutstein, T., Castello, M. A., Viechweg, S. S., Hadjimarkou, M. M., McQuail, J. A., Holder, M., et al. (2013). Differential responses of hippocampal neurons and astrocytes to nicotine and hypoxia in the fetal guinea pig. Neurotoxic. Res. 24, 80-93. doi: 10.1007/s12640-012-9363-2

Boland, M. J., Nazor, K. L., and Loring, J. F. (2014). Epigenetic regulation of pluripotency and differentiation. Circul. Res. 115, 311-324. doi: 10.1161/ CIRCRESAHA.115.301517

Buwalda, B., Nyakas, C., Vosselman, H. J., and Luiten, P. G. (1995). Effects of early postnatal anoxia on adult learning and emotion in rats. Behav. Brain Res. 67, 85-90. doi: 10.1016/0166-4328(94)00108-r

Cai, Z., Xiao, F., Lee, B., Paul, I. A., and Rhodes, P. G. (1999). Prenatal hypoxiaischemia alters expression and activity of nitric oxide synthase in the young rat brain and causes learning deficits. Brain Res. Bull. 49, 359-365. doi: 10.1016/ s0361-9230(99)00076-3

Camm, E. J., Cross, C. M., Kane, A. D., Tarry-Adkins, J. L., Ozanne, S. E., and Giussani, D. A. (2021). Maternal antioxidant treatment protects adult offspring against memory loss and hippocampal atrophy in a rodent model of developmental hypoxia. FASEB J. 35:e21477. doi: 10.1096/fj.202002557RR

Camm, E. J., Gibbs, M. E., and Harding, R. (2001). Restriction of prenatal gas exchange impairs memory consolidation in the chick. Brain Res. Dev. Brain Res. 132, 141-150. doi: 10.1016/s0165-3806(01)00305-4

Camm, E. J., Gibbs, M. E., Harding, R., Mulder, T., and Rees, S. M. (2005). Prenatal hypoxia impairs memory function but does not result in overt structural alterations in the postnatal chick brain. Brain Res. Dev. Brain Res. 160, 9-18. doi: 10.1016/j.devbrainres.2005.07.015

Cannon, T. D., Yolken, R., Buka, S., Torrey, E. F., and Collaborative Study Group on the Perinatal Origins of Severe Psychiatric, D. (2008). Decreased

\section{AUTHOR CONTRIBUTIONS}

MS conceived and supervised the project. BW, HZ, and JL wrote the manuscript. All authors contributed to the article and approved the submitted version.

\section{FUNDING}

This work was supported by grants from the National Key R\&D Program of China (2019YFA0802600), the National Natural Science Foundation of China (81974244 and 81570960), and the Natural Science Foundation of Jiangsu Province (BK20210092).

neurotrophic response to birth hypoxia in the etiology of schizophrenia. Biol. Psychiatry 64, 797-802. doi: 10.1016/j.biopsych.2008.04.012

Chen, Q., Zhang, F., Wang, Y., Liu, Z., Sun, A., Zen, K., et al. (2015). The transcription factor c-Myc suppresses MiR-23b and MiR-27b transcription during fetal distress and increases the sensitivity of neurons to hypoxia-induced apoptosis. PLoS One 10:e0120217. doi: 10.1371/journal.pone.0120217

Chen, X., Qi, L., Su, H., He, Y., Li, N., Gao, Q., et al. (2020). Prenatal hypoxia attenuated contraction of offspring coronary artery associated with decreased PKCbeta Ser(660) phosphorylation and intracellular calcium. Life Sci. 261:118364. doi: 10.1016/j.lfs.2020.118364

Chung, Y., So, K., Kim, E., Kim, S., and Jeon, Y. (2015). Immunoreactivity of neurogenic factor in the guinea pig brain after prenatal hypoxia. Ann. Anat. 200, 66-72. doi: 10.1016/j.aanat.2015.02.003

Collingridge, G. L., Isaac, J. T., and Wang, Y. T. (2004). Receptor trafficking and synaptic plasticity. Nat. Rev. Neurosci. 5, 952-962. doi: 10.1038/nrn1556

Cunha-Rodrigues, M. C., Balduci, C., Tenorio, F., and Barradas, P. C. (2018). GABA function may be related to the impairment of learning and memory caused by systemic prenatal hypoxia-ischemia. Neurobiol. Learn. Memory 149, 20-27. doi: 10.1016/j.nlm.2018.01.004

Delcour, M., Olivier, P., Chambon, C., Pansiot, J., Russier, M., Liberge, M., et al. (2012a). Neuroanatomical, sensorimotor and cognitive deficits in adult rats with white matter injury following prenatal ischemia. Brain Pathol. 22, 1-16. doi: 10.1111/j.1750-3639.2011.00504.x

Delcour, M., Russier, M., Amin, M., Baud, O., Paban, V., Barbe, M.F., et al. (2012b). Impact of prenatal ischemia on behavior, cognitive abilities and neuroanatomy in adult rats with white matter damage. Behav. brain res. 23, 233-244. doi: 10.1016/j.bbr.2012.03.029

Derrick, M., Luo, N. L., Bregman, J. C., Jilling, T., Ji, X., Fisher, K., et al. (2004). Preterm fetal hypoxia-ischemia causes hypertonia and motor deficits in the neonatal rabbit: a model for human cerebral palsy? J. Neurosci. 24, 24-34. doi: 10.1523/JNEUROSCI.2816-03.2004

Driscoll, D. J. O., Felice, V. D., Kenny, L. C., Boylan, G. B., and O’Keeffe, G. W. (2018). Mild prenatal hypoxia-ischemia leads to social deficits and central and peripheral inflammation in exposed offspring. Brain Behav. Immun. 69, 418-427. doi: 10.1016/j.bbi.2018.01.001

Dubrovskaia, N. M., Nalivaeva, N. N., Plesneva, S. A., Feponova, A. A., Turner, A. J., and Zhuravin, I. A. (2009). [Changes in the activity of amyloid-degrading metallopeptidases leads to disruption of memory in rats]. Zhurnal vysshei Nervnoi Deiatelnosti Imeni I P Pavlova 59, 630-638.

Dubrovskaia, N. M., and Zhuravin, I. A. (2008). Specificity of ontogenic development of behavior of rats subjected to prenatal hypoxia on the 14-th or 18-th days of embryogenesis. Zhurnal Vysshei Nervnoi Deiatelnosti Imeni I P Pavlova 58, 718-727.

Dubrovskaya, N. M., and Zhuravin, I. A. (2010). Ontogenetic characteristics of behavior in rats subjected to hypoxia on day 14 or day 18 of embryogenesis. Neurosci. Behav. Physiol. 40, 231-238. doi: 10.1007/s11055-009-9235-2

Dumas, T. C., Gillette, T., Ferguson, D., Hamilton, K., and Sapolsky, R. M. (2010). Anti-glucocorticoid gene therapy reverses the impairing effects of elevated corticosterone on spatial memory, hippocampal neuronal excitability, and 
synaptic plasticity. J. Neurosci. 30, 1712-1720. doi: 10.1523/JNEUROSCI.440209.2010

Duran-Carabali, L. E., Sanches, E. F., Reichert, L., and Netto, C. A. (2019). Enriched experience during pregnancy and lactation protects against motor impairments induced by neonatal hypoxia-ischemia. Behav. Brain Res. 367, 189-193. doi: 10.1016/j.bbr.2019.03.048

Ellison, V. J., Mocatta, T. J., Winterbourn, C. C., Darlow, B. A., Volpe, J. J., and Inder, T. E. (2005). The relationship of CSF and plasma cytokine levels to cerebral white matter injury in the premature newborn. Pediatric Res. 57, 282-286. doi: 10.1203/01.PDR.0000148286.53572.95

Esih, K., Goricar, K., Dolzan, V., and Rener-Primec, Z. (2017). Antioxidant polymorphisms do not influence the risk of epilepsy or its drug resistance after neonatal hypoxic-ischemic brain injury. Seizure 46, 38-42. doi: 10.1016/ j.seizure.2017.01.005

Foley, A. G., Murphy, K. J., and Regan, C. M. (2005). Complex-environment rearing prevents prenatal hypoxia-induced deficits in hippocampal cellular mechanisms necessary for memory consolidation in the adult Wistar rat. J. Neurosci. Res. 82, 245-254. doi: 10.1002/jnr.20641

Fowden, A. L., and Forhead, A. J. (2004). Endocrine mechanisms of intrauterine programming. Reproduction. 127, 515-526. doi: 10.1530/rep.1.00033

Fowden, A. L., Giussani, D. A., and Forhead, A. J. (2005). Endocrine and metabolic programming during intrauterine development. Early Human Dev. 81, 723734. doi: 10.1016/j.earlhumdev.2005.06.007

Gabrielli, L., Bonasoni, M. P., Santini, D., Piccirilli, G., Chiereghin, A., Petrisli, E., et al. (2012). Congenital cytomegalovirus infection: patterns of fetal brain damage. Clin. Microb. Infect. 18, E419-E427. doi: 10.1111/j.1469-0691.2012. 03983.x

Ganguly, E., Kirschenman, R., Spaans, F., Holody, C. D., Phillips, T. E. J., Case, C. P., et al. (2021). Nanoparticle-encapsulated antioxidant improves placental mitochondrial function in a sexually dimorphic manner in a rat model of prenatal hypoxia. FASEB J. 35:e21338. doi: 10.1096/fj.202002193R

Getahun, D., Rhoads, G. G., Demissie, K., Lu, S. E., Quinn, V. P., Fassett, M. J., et al. (2013). In utero exposure to ischemic-hypoxic conditions and attentiondeficit/hyperactivity disorder. Pediatrics 131, e53-e61. doi: 10.1542/peds.20121298

Ghotbeddin, Z., Tabandeh, M. R., Pourmahdi Borujeni, M., Fahimi Truski, F., Zalaki Ghorbani Pour, M. R., et al. (2021). Crocin mitigated cognitive impairment and brain molecular alterations induced by different intensities of prenatal hypoxia in neonatal rats. Brain Behav. 11:e02078. doi: 10.1002/brb3. 2078

Giannopoulou, I., Pagida, M. A., Briana, D. D., and Panayotacopoulou, M. T. (2018). Perinatal hypoxia as a risk factor for psychopathology later in life: the role of dopamine and neurotrophins. Hormones. 17, 25-32. doi: 10.1007/ s42000-018-0007-7

Golan, H., and Huleihel, M. (2006). The effect of prenatal hypoxia on brain development: short- and long-term consequences demonstrated in rodent models. Dev. Sci. 9, 338-349. doi: 10.1111/j.1467-7687.2006.00498.x

Golan, H., Kashtuzki, I., Hallak, M., Sorokin, Y., and Huleihel, M. (2004). Maternal hypoxia during pregnancy induces fetal neurodevelopmental brain damage: partial protection by magnesium sulfate. J. Neurosci. Res. 78, 430-441. doi: 10.1002/jnr.20269

Golan, M. H., Mane, R., Molczadzki, G., Zuckerman, M., Kaplan-Louson, V., Huleihel, M., et al. (2009). Impaired migration signaling in the hippocampus following prenatal hypoxia. Neuropharmacology 57, 511-522. doi: 10.1016/j. neuropharm.2009.07.028

Gonzalez-Rodriguez, P. J., Xiong, F., Li, Y., Zhou, J., and Zhang, L. (2014). Fetal hypoxia increases vulnerability of hypoxic-ischemic brain injury in neonatal rats: role of glucocorticoid receptors. Neurob. Dis. 65, 172-179. doi: 10.1016/ j.nbd.2014.01.020

Gopagondanahalli, K. R., Li, J., Fahey, M. C., Hunt, R. W., Jenkin, G., Miller, S. L., et al. (2016). Preterm Hypoxic-Ischemic Encephalopathy. Front. Pediatr. 4:114. doi: 10.3389/fped.2016.00114

Gumusoglu, S. B., Chilukuri, A. S. S., Santillan, D. A., Santillan, M. K., and Stevens, H. E. (2020). Neurodevelopmental Outcomes of Prenatal Preeclampsia Exposure. Trends Neurosci. 43, 253-268. doi: 10.1016/j.tins.2020.02.003

Hennigan, A., O’Callaghan, R. M., and Kelly, A. M. (2007). Neurotrophins and their receptors: roles in plasticity, neurodegeneration and neuroprotection. Biochem. Soc. Trans. 35, 424-427. doi: 10.1042/BST0350424
Herlenius, E., and Lagercrantz, H. (2004). Development of neurotransmitter systems during critical periods. Exp. Neurol. 190(Suppl. 1), S8-S21. doi: 10. 1016/j.expneurol.2004.03.027

Hermans, R. H., McGivern, R. F., Chen, W., and Longo, L. D. (1993). Altered adult sexual behavior in the male rat following chronic prenatal hypoxia. Neurotoxicol. Teratol. 15, 353-363. doi: 10.1016/0892-0362(93)90051-o

Hoeger, H., Engelmann, M., Bernert, G., Seidl, R., Bubna-Littitz, H., Mosgoeller, W., et al. (2000). Long term neurological and behavioral effects of graded perinatal asphyxia in the rat. Life Sci. 66, 947-962. doi: 10.1016/s0024-3205(99) 00678-5

Howell, K. R., and Pillai, A. (2016). Long-Term Effects of Prenatal Hypoxia on Schizophrenia-Like Phenotype in Heterozygous Reeler Mice. Mole. Neurob. 53, 3267-3276. doi: 10.1007/s12035-015-9265-4

Jellema, R. K., Lima Passos, V., Zwanenburg, A., Ophelders, D. R., De Munter, S., Vanderlocht, J., et al. (2013). Cerebral inflammation and mobilization of the peripheral immune system following global hypoxia-ischemia in preterm sheep. J. Neuroinflam. 10:13. doi: 10.1186/1742-2094-10-13

Jensen, A., Garnier, Y., and Berger, R. (1999). Dynamics of fetal circulatory responses to hypoxia and asphyxia. Eur. J. Obst. Gynecol. Reprod. Biol. 84, 155-172. doi: 10.1016/s0301-2115(98)00325-x

Jia, L., Wang, J., Cao, H., Zhang, X., Rong, W., and Xu, Z. (2020). Activation of PGC-1alpha and Mitochondrial Biogenesis Protects Against Prenatal Hypoxicischemic Brain Injury. Neuroscience. 432, 63-72. doi: 10.1016/j.neuroscience. 2020.02.035

Khalaf-Nazzal, R., and Francis, F. (2013). Hippocampal development - old and new findings. Neuroscience 248, 225-242. doi: 10.1016/j.neuroscience.2013.05.061

Killiany, R. J., Hyman, B. T., Gomez-Isla, T., Moss, M. B., Kikinis, R., Jolesz, F., et al. (2002). MRI measures of entorhinal cortex vs hippocampus in preclinical AD. Neurology 58, 1188-1196. doi: 10.1212/wnl.58.8 .1188

Koundal, S., Gandhi, S., Kaur, T., and Khushu, S. (2014). Neurometabolic and structural alterations in rat brain due to acute hypobaric hypoxia: in vivo $1 \mathrm{H}$ MRS at 7 T. NMR Biomed. 27, 341-347. doi: 10.1002/nbm.3068

Kozlova, D. I., Vasylev, D. S., Dubrovskaya, N. M., Nalivaeva, N. N., Tumanova, N. L., and Zhuravin, I. A. (2015). [Role Of Caspase-3 In Regulation Of the Content Of the Amyloid-Degrading Neuropeptidase Neprilysin In the Cortex Of Rats after Hypoxia]. Zhurnal Evoliutsionnoi Biokhimii i Fiziologii 51, 427430.

Lacan, L., Hamoud, Y., Nguyen, S., De Jonckheere, J., Storme, L., Houfflin-Debarge, V., et al. (2020). Fetal sheep cerebral electrical activity: A new technique to record EEG. J. Neurosci. Methods 345:108888. doi: 10.1016/j.jneumeth.2020. 108888

Lawrence, K. M., McGovern, P. E., Mejaddam, A., Rossidis, A. C., Baumgarten, H., Kim, A., et al. (2019). Chronic intrauterine hypoxia alters neurodevelopment in fetal sheep. J. Thoracic Cardiovasc. Surg. 157, 1982-1991. doi: 10.1016/j.jtcvs. 2018.12.093

Lee, A. L., Ogle, W. O., and Sapolsky, R. M. (2002). Stress and depression: possible links to neuron death in the hippocampus. Bipol. Dis. 4, 117-128. doi: 10.1034/ j.1399-5618.2002.01144.x

Liang, H., Studach, L., Hullinger, R. L., Xie, J., and Andrisani, O. M. (2014). Down-regulation of RE-1 silencing transcription factor (REST) in advanced prostate cancer by hypoxia-induced miR-106b 25. Exp. Cell Res. 320, 188-199. doi: 10.1016/j.yexcr.2013.09.020

Liu, F. J., Kaur, P., Karolina, D. S., Sepramaniam, S., Armugam, A., Wong, P. T., et al. (2015). MiR-335 Regulates Hif-1alpha to Reduce Cell Death in Both Mouse Cell Line and Rat Ischemic Models. PLoS One 10:e0128432. doi: 10.1371/ journal.pone.0128432

Liu, H., Qiu, H., Yang, J., Ni, J., and Le, W. (2016). Chronic hypoxia facilitates Alzheimer's disease through demethylation of gamma-secretase by downregulating DNA methyltransferase 3b. Alzheimer Dementia 12, 130-143. doi: 10.1016/j.jalz.2015.05.019

Louzoun-Kaplan, V., Zuckerman, M., Perez-Polo, J. R., and Golan, H. M. (2008). Prenatal hypoxia down regulates the GABA pathway in newborn mice cerebral cortex; partial protection by MgSO4. Internat. J. Dev. Neurosci. 26, 77-85. doi: 10.1016/j.ijdevneu.2007.09.002

Lubec, B., Labudova, O., Hoeger, H., Kirchner, L., and Lubec, G. (2002). Expression of transcription factors in the brain of rats with perinatal asphyxia. Biol. Neonate 81, 266-278. doi: 10.1159/000056758 
Malamitsi-Puchner, A., Nikolaou, K. E., Economou, E., Boutsikou, M., Boutsikou, T., Kyriakakou, M., et al. (2007). Intrauterine growth restriction and circulating neurotrophin levels at term. Early Hum. Dev. 83, 465-469. doi: 10.1016/j. earlhumdev.2006.09.001

Martin-Ancel, A., Garcia-Alix, A., Pascual-Salcedo, D., Cabanas, F., Valcarce, M., and Quero, J. (1997). Interleukin-6 in the cerebrospinal fluid after perinatal asphyxia is related to early and late neurological manifestations. Pediatrics 100, 789-794. doi: 10.1542/peds.100.5.789

Martinez-Biarge, M., Diez-Sebastian, J., Rutherford, M. A., and Cowan, F. M. (2010). Outcomes after central grey matter injury in term perinatal hypoxicischaemic encephalopathy. Early Hum. Dev. 86, 675-682. doi: 10.1016/j. earlhumdev.2010.08.013

Maulik, D., Mishra, O. P., and Delivoria-Papadopoulos, M. (2005). Effect of post-hypoxic $\mathrm{MgSO}(4)$ administration in utero on $\mathrm{Ca}(2+)$-influx and $\mathrm{Ca}(2+) /$ calmodulin kinase IV activity in cortical neuronal nuclei. Neurosci. Lett. 386, 127-132. doi: 10.1016/j.neulet.2005.05.064

Mayoral, S. R., Omar, G., and Penn, A. A. (2009). Sex differences in a hypoxia model of preterm brain damage. Pediatric Res. 66, 248-253. doi: 10.1203/PDR. 0b013e3181b1bc34

McClendon, E., Shaver, D. C., Degener-O’Brien, K., Gong, X., Nguyen, T., HoerderSuabedissen, A., et al. (2017). Transient Hypoxemia Chronically Disrupts Maturation of Preterm Fetal Ovine Subplate Neuron Arborization and Activity. J. Neurosci. 37, 11912-11929. doi: 10.1523/JNEUROSCI.2396-17.2017

McGovern, P. E., Lawrence, K., Baumgarten, H., Rossidis, A. C., Mejaddam, A. Y., Licht, D. J., et al. (2020). Ex Utero Extracorporeal Support as a Model for Fetal Hypoxia and Brain Dysmaturity. Ann. Surg. 109, 810-819. doi: 10.1016/j. athoracsur.2019.08.021

Miyamoto, O., and Auer, R. N. (2000). Hypoxia, hyperoxia, ischemia, and brain necrosis. Neurology 54, 362-371. doi: 10.1212/wnl.54.2.362

Morales, P., Bustamante, D., Espina-Marchant, P., Neira-Pena, T., GutierrezHernandez, M. A., Allende-Castro, C., et al. (2011). Pathophysiology of perinatal asphyxia: can we predict and improve individual outcomes? EPMA J. 2, 211-230. doi: 10.1007/s13167-011-0100-3

Murphy, B. P., Inder, T. E., Huppi, P. S., Warfield, S., Zientara, G. P., Kikinis, R., et al. (2001). Impaired cerebral cortical gray matter growth after treatment with dexamethasone for neonatal chronic lung disease. Pediatrics 107, 217-221. doi: 10.1542/peds.107.2.217

Mutoh, T., Sanosaka, T., Ito, K., and Nakashima, K. (2012). Oxygen levels epigenetically regulate fate switching of neural precursor cells via hypoxiainducible factor 1alpha-notch signal interaction in the developing brain. Stem Cells 30, 561-569. doi: 10.1002/stem.1019

Myatt, L. (2006). Placental adaptive responses and fetal programming. J. Physiol. 572, 25-30. doi: 10.1113/jphysiol.2006.104968

Nalivaeva, N. N., Belyaev, N. D., Lewis, D. I., Pickles, A. R., Makova, N. Z., Bagrova, D. I., et al. (2012). Effect of sodium valproate administration on brain neprilysin expression and memory in rats. J. Mole. Neurosci. 46, 569-577. doi: 10.1007/ s12031-011-9644-x

Nalivaeva, N. N., Turner, A. J., and Zhuravin, I. A. (2018). Role of Prenatal Hypoxia in Brain Development, Cognitive Functions, and Neurodegeneration. Front. Neurosci. 12:825. doi: 10.3389/fnins.2018.00825

Nguyen, M. P., Lee, S., and Lee, Y. M. (2013). Epigenetic regulation of hypoxia inducible factor in diseases and therapeutics. Archiv. Pharm. Res. 36, 252-263. doi: 10.1007/s12272-013-0058-x

Nikolaou, K. E., Malamitsi-Puchner, A., Boutsikou, T., Economou, E., Boutsikou, M., Puchner, K. P., et al. (2006). The varying patterns of neurotrophin changes in the perinatal period. Ann. NY Acad. Sci. 1092, 426-433. doi: 10.1196/annals. 1365.041

Nyakas, C., Buwalda, B., Kramers, R. J., Traber, J., and Luiten, P. G. (1994). Postnatal development of hippocampal and neocortical cholinergic and serotonergic innervation in rat: effects of nitrite-induced prenatal hypoxia and nimodipine treatment. Neuroscience 59, 541-559. doi: 10.1016/0306-4522(94) 90176-7

O'Sullivan, L., Combes, A. N., and Moritz, K. M. (2012). Epigenetics and developmental programming of adult onset diseases. Pediatric Nephrol. 27, 2175-2182. doi: 10.1007/s00467-012-2108-x

Osumek, J. E., Revesz, A., Morton, J. S., Davidge, S. T., and Hardy, D. B. (2014). Enhanced trimethylation of histone h3 mediates impaired expression of hepatic glucose 6-phosphatase expression in offspring from rat dams exposed to hypoxia during pregnancy. Reproduct. Sci. 21, 112-121. doi: 10.1177/ 1933719113492212

Owens, E. B., and Hinshaw, S. P. (2013). Perinatal problems and psychiatric comorbidity among children with ADHD. J. Clin. Child Adoles. Psychol. 42, 762-768. doi: 10.1080/15374416.2013.785359

Patterson, A. J., and Zhang, L. (2010). Hypoxia and fetal heart development. Curr. Mole. Med. 10, 653-666. doi: 10.2174/156652410792630643

Piesova, M., Koprdova, M., Ujhazy, E., Krskova, L., Olexova, L., Morova, M., et al. (2020). Impact of prenatal hypoxia on the development and behavior of the rat offspring. Physiol. Res. 69, S649-S659.

Piesova, M., and Mach, M. (2020). Impact of perinatal hypoxia on the developing brain. Physiol. Res. 69, 199-213. doi: 10.33549/physiolres.934198

Poyton, R. O., Ball, K. A., and Castello, P. R. (2009). Mitochondrial generation of free radicals and hypoxic signaling. Trends Endocrinol. Metab. 20, 332-340. doi: 10.1016/j.tem.2009.04.001

Richardson, B., Korkola, S., Asano, H., Challis, J., Polk, D., and Fraser, M. (1996). Regional blood flow and the endocrine response to sustained hypoxemia in the preterm ovine fetus. Pediatric Res. 40, 337-343. doi: 10.1203/00006450199608000-00024

Riljak, V., Kraf, J., Daryanani, A., Jiruska, P., and Otahal, J. (2016). Pathophysiology of perinatal hypoxic-ischemic encephalopathy - biomarkers, animal models and treatment perspectives. Physiol. Res. 65, S533-S545. doi: 10.33549/physiolres. 933541

Robinson, S., Petelenz, K., Li, Q., Cohen, M. L., Dechant, A., Tabrizi, N., et al. (2005). Developmental changes induced by graded prenatal systemic hypoxicischemic insults in rats. Neurobiol. Dis. 18, 568-581. doi: 10.1016/j.nbd.2004.10. 024

Royer, C., Lachuer, J., Crouzoulon, G., Roux, J., Peyronnet, J., Mamet, J., et al. (2000). Effects of gestational hypoxia on mRNA levels of Glut3 and Glut4 transporters, hypoxia inducible factor-1 and thyroid hormone receptors in developing rat brain. Brain Res. 856, 119-128. doi: 10.1016/s0006-8993(99) 02365-3

Sab, I. M., Ferraz, M. M., Amaral, T. A., Resende, A. C., Ferraz, M. R., Matsuura, C., et al. (2013). Prenatal hypoxia, habituation memory and oxidative stress. Pharm. Biochem. Behav. 107, 24-28. doi: 10.1016/j.pbb.2013.04.004

Saliba, E., and Henrot, A. (2001). Inflammatory mediators and neonatal brain damage. Biol. Neonate 79, 224-227. doi: 10.1159/000047096

Sandau, U. S., and Handa, R. J. (2007). Glucocorticoids exacerbate hypoxiainduced expression of the pro-apoptotic gene Bnip3 in the developing cortex. Neuroscience 144, 482-494. doi: 10.1016/j.neuroscience.2006.10.003

Sedaghat, K., Zahediasl, S., and Ghasemi, A. (2015). Intrauterine programming. Iran. J. Basic Med. Sci. 18, 212-220.

Sedlackova, N., Krajciova, M., Koprdova, R., Ujhazy, E., Brucknerova, I., and Mach, M. (2014). Subchronic perinatal asphyxia increased anxiety-and depression-like behaviors in the rat offspring. Neuro Endocrinol. Lett. 35(Suppl. 2), 214-220.

Semenza, G. L. (1998). Hypoxia-inducible factor 1: master regulator of O2 homeostasis. Curr. Opin. Genet. Dev. 8, 588-594. doi: 10.1016/s0959-437x(98) 80016-6

Shepherd, E., Salam, R. A., Middleton, P., Makrides, M., McIntyre, S., Badawi, N., et al. (2017). Antenatal and intrapartum interventions for preventing cerebral palsy: an overview of Cochrane systematic reviews. Cochr. Database Syst. Rev. 8:CD012077. doi: 10.1002/14651858.CD012077.pub2

Shi, Y. J., Ma, Z. Q., Tang, J. W., Zhao, Y., Wang, X., Liu, Q., et al. (2017). The integration of multiple signaling pathways provides for bidirectional control of CRHR1 gene transcription in rat pituitary cell during hypoxia. Mole. Cell. Endocrinol. 454, 12-22. doi: 10.1016/j.mce.2017.05 .031

Silveira, R. C., and Procianoy, R. S. (2015). Hypothermia therapy for newborns with hypoxic ischemic encephalopathy. Jornal de pediatria. 91, S78-S83. doi: 10.1016/j.jped.2015.07.004

Silvestro, S., Calcaterra, V., Pelizzo, G., Bramanti, P., and Mazzon, E. (2020). Prenatal Hypoxia and Placental Oxidative Stress: Insights from Animal Models to Clinical Evidences. Antioxidants 9:9050414. doi: 10.3390/antiox90 50414

Smith, T. F., Schmidt-Kastner, R., McGeary, J. E., Kaczorowski, J. A., and Knopik, V. S. (2016). Pre- and Perinatal Ischemia-Hypoxia, the Ischemia-Hypoxia Response Pathway, and ADHD Risk. Behav. Genet. 46, 467-477. doi: 10.1007/ s10519-016-9784-4 
So, K., Chung, Y., Yu, S. K., and Jun, Y. (2017). Regional Immunoreactivity of Pax6 in the Neurogenic Zone After Chronic Prenatal Hypoxia. In Vivo 31, 1125-1129. doi: 10.21873/invivo.11178

Sosedova, L. M., Vokina, V. A., and Kapustina, E. A. (2019). Contribution of Fetal Programming in the Formation of Cognitive Impairments Induced by Lead Poisoning in White Rats. Bull. Exp. Biol. Med. 166, 617-621. doi: 10.1007/ s10517-019-04404-4

Stein-Behrens, B. A., Elliott, E. M., Miller, C. A., Schilling, J. W., Newcombe, R., and Sapolsky, R. M. (1992). Glucocorticoids exacerbate kainic acid-induced extracellular accumulation of excitatory amino acids in the rat hippocampus. J. Neurochem. 58, 1730-1735. doi: 10.1111/j.1471-4159.1992.tb10047.x

Su, H., Chen, X., Zhang, Y., Qi, L., He, Y., Lv, J., et al. (2020). In utero hypoxia altered Ang II-induced contraction via PKCbeta in fetal cerebral arteries. J. Endocrinol. 244, 213-222. doi: 10.1530/JOE-19-0370

Tachibana, R., Umekawa, T., Yoshikawa, K., Owa, T., Magawa, S., Furuhashi, F., et al. (2019). Tadalafil treatment in mice for preeclampsia with fetal growth restriction has neuro-benefic effects in offspring through modulating prenatal hypoxic conditions. Sci. Rep. 9:234. doi: 10.1038/s41598-018-36084-x

Taguchi, A., Yanagisawa, K., Tanaka, M., Cao, K., Matsuyama, Y., Goto, H., et al. (2008). Identification of hypoxia-inducible factor-1 alpha as a novel target for miR-17-92 microRNA cluster. Cancer Res. 68, 5540-5545. doi: 10.1158/00085472.CAN-07-6460

Tong, W., Chen, W., Ostrowski, R. P., Ma, Q., Souvenir, R., Zhang, L., et al. (2010). Maternal hypoxia increases the activity of MMPs and decreases the expression of TIMPs in the brain of neonatal rats. Dev. Neurob. 70, 182-194. doi: 10.1002/dneu.20770

Twomey, E., Twomey, A., Ryan, S., Murphy, J., and Donoghue, V. B. (2010). MR imaging of term infants with hypoxic-ischaemic encephalopathy as a predictor of neurodevelopmental outcome and late MRI appearances. Pediatric Radiol. 40, 1526-1535. doi: 10.1007/s00247-010-1692-9

Van de Berg, W. D., Schmitz, C., Steinbusch, H. W., and Blanco, C. E. (2002). Perinatal asphyxia induced neuronal loss by apoptosis in the neonatal rat striatum: a combined TUNEL and stereological study. Exp. Neurol. 174, 29-36. doi: 10.1006/exnr.2001.7855

Vasilev, D. S., Dubrovskaya, N. M., Tumanova, N. L., and Zhuravin, I. A. (2016). Prenatal Hypoxia in Different Periods of Embryogenesis Differentially Affects Cell Migration, Neuronal Plasticity, and Rat Behavior in Postnatal Ontogenesis. Front. Neurosci. 10:126. doi: 10.3389/fnins.2016.00126

Vetrovoy, O., Tyulkova, E., Stratilov, V., Baranova, K., Nimiritsky, P., Makarevich, P., et al. (2020). Long-Term Effects of Prenatal Severe Hypoxia on Central and Peripheral Components of the Glucocorticoid System in Rats. Dev. Neurosci. 42, 145-158. doi: 10.1159/000512223

Wang, X., Meng, F. S., Liu, Z. Y., Fan, J. M., Hao, K., Chen, X. Q., et al. (2013). Gestational hypoxia induces sex-differential methylation of Crhr1 linked to anxiety-like behavior. Mole. Neurob. 48, 544-555. doi: 10.1007/s12035-0138444- 4

Wei, B., Li, L., He, A., Zhang, Y., Sun, M., and Xu, Z. (2016). Hippocampal NMDAR-Wnt-Catenin signaling disrupted with cognitive deficits in adolescent offspring exposed to prenatal hypoxia. Brain Res. 1631, 157-164. doi: 10.1016/j. brainres.2015.11.041

Weitzdoerfer, R., Gerstl, N., Pollak, D., Hoeger, H., Dreher, W., and Lubec, G. (2004). Long-term influence of perinatal asphyxia on the social behavior in aging rats. Gerontology 50, 200-205. doi: 10.1159/000078348
Yeh, T. F., Lin, Y. J., Lin, H. C., Huang, C. C., Hsieh, W. S., Lin, C. H., et al. (2004). Outcomes at school age after postnatal dexamethasone therapy for lung disease of prematurity. New Engl. J. Med. 350, 1304-1313. doi: 10.1056/NEJMoa032089

Zamudio, S. (2003). The placenta at high altitude. High Altit. Med. Biol. 4, 171-191. doi: 10.1089/152702903322022785

Zhang, C., Xu, D., Luo, H., Lu, J., Liu, L., Ping, J., et al. (2014). Prenatal xenobiotic exposure and intrauterine hypothalamus-pituitary-adrenal axis programming alteration. Toxicology 325, 74-84. doi: 10.1016/j.tox.2014.08.015

Zhang, X., Li, L., Zhang, X., Xie, W., Li, L., Yang, D., et al. (2013). Prenatal hypoxia may aggravate the cognitive impairment and Alzheimer's disease neuropathology in APPSwe/PS1A246E transgenic mice. Neurobiol. Aging 34, 663-678. doi: 10.1016/j.neurobiolaging.2012.06.012

Zhao, M., Zhu, P., Fujino, M., Zhuang, J., Guo, H., Sheikh, I., et al. (2016). Oxidative Stress in Hypoxic-Ischemic Encephalopathy: Molecular Mechanisms and Therapeutic Strategies. Internat. J. Mole. Sci. 17:17122078. doi: 10.3390/ ijms 17122078

Zhu, T., Gan, J., Huang, J., Li, Y., Qu, Y., and Mu, D. (2016). Association Between Perinatal Hypoxic-Ischemic Conditions and Attention-Deficit/Hyperactivity Disorder: A Meta-Analysis. J. Child Neurol. 31, 1235-1244. doi: 10.1177/ 0883073816650039

Zhuravin, I. A., Dubrovskaya, N. M., and Plesneva, S. A. (2002). Striatal level of regulation of learned forepaw movements in rats. Physiol. Res. 51(Suppl. 1), S67-S76.

Zhuravin, I. A., Dubrovskaya, N. M., Vasilev, D. S., Postnikova, T. Y., and Zaitsev, A. V. (2019). Prenatal hypoxia produces memory deficits associated with impairment of long-term synaptic plasticity in young rats. Neurob. Learn. Memory 164:107066. doi: 10.1016/j.nlm.2019.107066

Zhuravin, I. A., Dubrovskaya, N. M., Vasilev, D. S., Tumanova, N. L., and Nalivaeva, N. N. (2011). Epigenetic and pharmacological regulation of the amyloiddegrading enzyme neprilysin results in modulation of cognitive functions in mammals. Doklady Biol. Sci. 438, 145-148. doi: 10.1134/S001249661103 $015 \mathrm{X}$

Zornberg, G. L., Buka, S. L., and Tsuang, M. T. (2000). Hypoxic-ischemia-related fetal/neonatal complications and risk of schizophrenia and other nonaffective psychoses: a 19-year longitudinal study. Am. J. Psychiatry 157, 196-202. doi: 10.1176/appi.ajp.157.2.196

Conflict of Interest: The authors declare that the research was conducted in the absence of any commercial or financial relationships that could be construed as a potential conflict of interest.

Publisher's Note: All claims expressed in this article are solely those of the authors and do not necessarily represent those of their affiliated organizations, or those of the publisher, the editors and the reviewers. Any product that may be evaluated in this article, or claim that may be made by its manufacturer, is not guaranteed or endorsed by the publisher.

Copyright (c) 2021 Wang, Zeng, Liu and Sun. This is an open-access article distributed under the terms of the Creative Commons Attribution License (CC BY). The use, distribution or reproduction in other forums is permitted, provided the original author(s) and the copyright owner(s) are credited and that the original publication in this journal is cited, in accordance with accepted academic practice. No use, distribution or reproduction is permitted which does not comply with these terms. 